IJLRES - International Journal on Language, Research and Education Studies

ISSN: 2580-6777 (p); 2580-6785 (e)

DOI: $10.30575 / 2017 /$ IJLRES-2018050812

Vol. 2, No. 2, 2018

Page: $294-311$

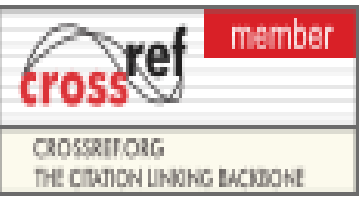

\title{
FRAMING ANALYSIS ON NEWS OF ISLAMIC STATE OF IRAQ AND SYIRIA IN WASPADA DAILY NEWS
}

\author{
Abdul Rasyid \\ Postgraduate School, State Islamic University of North Sumatra, Indonesia \\ abdulrasyid@gmail.com \\ Syukur Kholil \\ Postgraduate School, State Islamic University of North Sumatra, Indonesia \\ syukurkholil@uinsu.ac.id \\ Suwardi Lubis \\ Postgraduate School, State Islamic University of North Sumatra, Indonesia \\ suwardilubis@uinsu.ac.id
}

\begin{abstract}
This study aims to get the intent and purpose of news about ISIS in Haria Waspada. This study uses a descriptive qualitative approach in which the researcher describes the data that exist in Waspada by using Framing analysis, namely analysis with emphasis on; 1\} Scheme, 2\} Script, 3\} Thematics, and 4\} Rhetoric. The data in this study focuses on ISIS news in the Daily News of Waspada, in this study focused on 3 news which is phenomenal related to ISIS. The research results show that: 1 . In the scheme, all elements of the Daily Alert report have fulfilled the sheme requirements, wherein there must be a Headline, Lead, Background of Information, Statement and Closing. 2\} In Script, This Coverage has used a good script model which includes the script elements, they are; What, Who, Where, When, Why and How. 3$\}$ in thematics, the daily news of Waspada has fulfilled its elements, they are; Paragraph and Proportion. 4\} while in the Rhetoric element, the ISIS report on the Daily news of Waspada has included all elements of Rhetoric, they are; Words, Idiom Picture, and Graphic. In conclusion, Framing Analysis of news related to ISIS in the Daily News of waspada can be a scientific reference because it has fulfilled all the elements contained in the Framing analysis.
\end{abstract}

Keywords: Framing Analysis, ISIS, Waspada Daily News

\section{INTRODUCTION}

News of the Islamic State of Iraq and Syria (ISIS) has long been rolling in the mass media, including newspapers. Exactly after the US invaded Iraq in 2003 under the pretext of Iraq storing weapons of mass destruction. Various negative responses emerge, both the lower class and upper classes seem to think the same as what the mass media thinks. 
The study of ISIS news framing analysis is believed to be able to uncover the question of doubts about the ISIS news objectivity regarding British Women's Testimony About ISIS, news of France Inviting ISIS's Combating World Coalition, and news with the title ISIS Militant Executing her biological mother quoted by Waspada from AFP, Reuter, And, and CNN which is the product of the British, United States and Jewish news agencies.

Through framing analysis will be known who controls who, who opposed whom, where friends where opponents, where patrons and which clients, who benefits and who is harmed, who oppresses and who oppressed, and so on. Such conclusions are most likely to be obtained because framing analysis is an art of creativity that has freedom in interpreting reality by using certain theories and methodologies. There are two main essences of framing analysis, namely, First, how events are interpreted. This relates to which parts are covered and which are not covered. Second, how facts are written. This aspect relates to the use of words, sentences, and images to support ideas.

\section{LITERATURE REVIEW}

The ISIS is a direct result of al-Qaeda shards in Iraq that grew out of the US invasion which is an example of undesirable consequences. That is why we must have a purpose before we 'shoot'.Kendati so, Obama believes an international coalition of 60 countries will slowly eject ISIS out of Iraq.

According to Obama, the challenge to stop extremism will not stop, unless there is a political solution to internal conflicts that affect so many countries in the Middle East. If ISIS is defeated, there is a fundamental problem of Sunni majority countries around the world, especially in some areas including Libya and Yemen, where a young man grows without education, has no prospect of looking into the future

\section{The Territorial of ISIS}

The newest ISIS power region, ie, in August 2014, ISIS's territory includes red areas on the map below. 


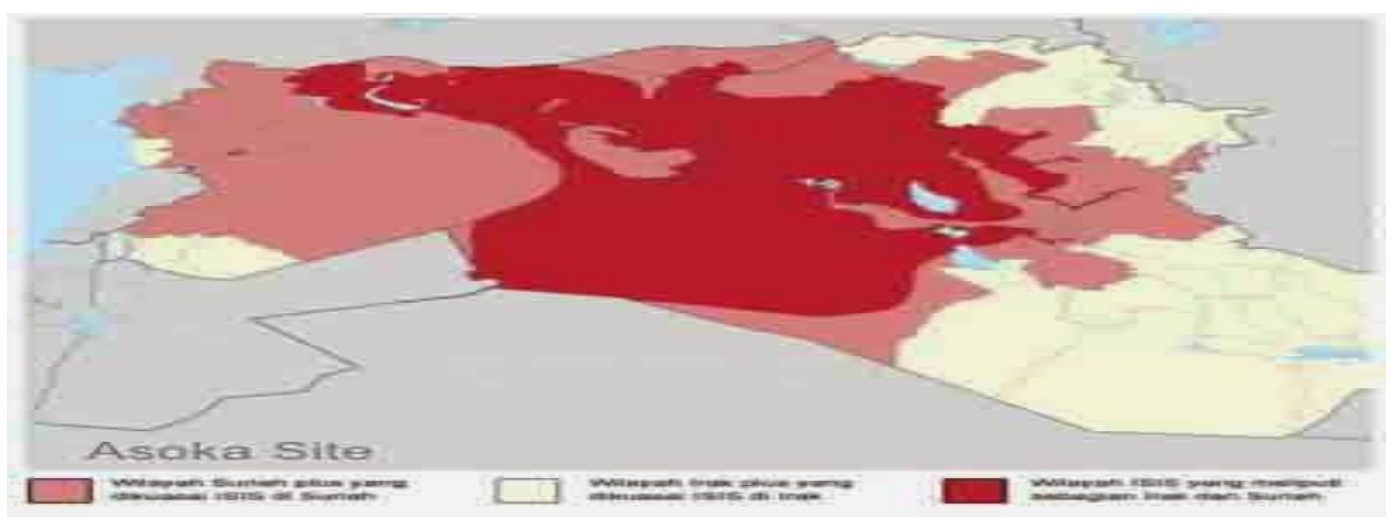

ISIS's power territory in Syria and Iraq

The extent of the ISIS colony makes them one of the richest terror groups in the world. Because, in their territory, millions of barrels of petroleum are stored as a source of coffers worth hundreds of millions of United States Dollars (USD).

In Syria, ISIS has captured eight oil fields in the provinces of Raqqa and Deir elZour. In Iraq, ISIS has four oil fields in Saladin province. At the end of 2014, the United Nations (UN) estimated that ISIS had scored USD 1.6 million or equivalent to IDR 21.9 billion per day from the sale of crude oil and processed on the black market.

\section{METHODOLOGY}

In this study, the research method used is descriptive-qualitative research method. Descriptive method in this study is intended to be able to describe the data obtained systematically, factually, and accurately about the facts contained in a text by the mass media. Furthermore, researchers as instruments of research conducted qualitative research.

\section{Technique of Data Analysis}

The data processing technique used in this study is the analysis framework of the framing formula of Zhongdang Pan and Gerald M. Kosicki, because the framing device examines the media through the structure of language used in constructing reality. This analysis model is right in processing the data obtained to answer the questions in the formulation of the problem that will produce a conclusion of the study. The frame analysis model developed by Zhongdang Pan and Gerald M. Kosicki is divided based on the structure of analysis which is divided into several sections as contained in the following table: 


\begin{tabular}{|c|c|c|}
\hline Structure & Framing Device & Observed Unit \\
\hline $\begin{array}{l}\text { SINTAX: } \\
\text { How reporters compile facts }\end{array}$ & 1. News Scheme & $\begin{array}{l}\text { Headline, lead, } \\
\text { Background of } \\
\text { information, Source, } \\
\text { Utterances, Closing }\end{array}$ \\
\hline $\begin{array}{l}\text { SCRIPT: } \\
\text { How journalists Tell the Story }\end{array}$ & 2. Completed news & $5 \mathrm{~W}+1 \mathrm{H}$ \\
\hline $\begin{array}{l}\text { THEMATIC: } \\
\text { How journalists write facts }\end{array}$ & $\begin{array}{l}\text { 3. Detail } \\
\text { 4. Purpose of Sentece } \\
\text { 5. Relatio of each Sentence } \\
\text { 6. Nominalization } \\
\text { 7. Coherence } \\
\text { 8. Sentence Format } \\
\text { 9. Auxialiary Verb }\end{array}$ & Paragraph, Proportion \\
\hline $\begin{array}{l}\text { RHETORIC: } \\
\text { The way journalists } \\
\text { emphasize facts }\end{array}$ & $\begin{array}{l}\text { 10. Lexicon } \\
\text { 11. Picture } \\
\text { 12. Metaphor } \\
\text { 13. Presupposition }\end{array}$ & $\begin{array}{l}\text { Word, Idiom, } \\
\text { Picture?Photo, grahics }\end{array}$ \\
\hline
\end{tabular}

\section{FINDING AND DISCUSSION}

\section{Framing Analysis on the News "French Invites the World Combining to Combat ISIS}

\section{Prancis Ajak Dunia Berkoalisi Perangi ISIS}

PARIS (Waspada): Presiden Prancis Francois Hollande mengajak Amerika Serikat (AS) dan Rusia Selasa (17/11) untuk membangun koalisi global guna memerangi ISIS setelah terjadinya serangkaian serangan di Paris Jumat lalu. "Prancis sedang berperang," ujar Hollande dalam sebuah pertemuan gabungan parlemen di Palace of Versailles, Prancis. Ia berjanji menambah dana untuk peningkatan keamanan dalam negeri dan memperkuat hukum anti terorisme.

"Kita sedang berperang melawan teroris jihad yang mengancam seluruh dunia," ujar Hollande lagi.Seorang juru bicara dari Komando Militer Prancis melaporkan pada Reuters Selasa bahwa 10 pesawat tempur Prancis, yang diluncurkan dari Yordania dan Uni Emirat Arabq, telah melakukan serangan udara yang menyasar pusat komando dan pusat pelatihan ISIS di Raqa,Syria.

ISIS sebelumnya mengaku bertanggung jawab melakukan penyerngan di Paris karena berkaitan dengan keikutsertaan Prancis dalam mendukung koalisi AS yang melancarkan serangan pada kelompok mereka di Irak dan Syria.Hollande akan melakukan pertemuan secepatnya dengan Presiden AS Barack Obama dan Presiden Rusia Vladimir Putin guna mendesak mereka agar bersatu.

"Kita harus menggabungkan kekuatan demi mendapatkan hasil yang sebenarnya sudah terlambat didapat," kata Hollande lagi.Koalisi yang dipimpin AS telah melakukan pemboman ISIS selama lebih dari satu tahun. Rusia ikut bergabung dalam konflik tersebut sejak September, namun pihak Barat mengatakan bahwa sasaran yang mereka tuju adalah milisi lawan Presiden Syria Bashar al-Assad yang mendapat dukungan dari asing, bukan ISIS.

Saat berbicara di Turki, Obama mengatakan bahwa serangan yang terjadi di Paris merupakan sebuah hal yang mengerikan, dan ia juga mengatakan bahwa koalisi gabungan mereka telah membuat kemajuan.Saat ini tim penyelidik telah mengidentifikasi seorang warga negara Belgia yang tinggal di Syria sebagai (kemungkinan besar) dalang serangan di Paris, yang menyasar bar, restoran, gedung konser, dan stadion sepakbola.

"Serangan yang terjadi Jumat lalu telah dirncanakan sebelumnya di Syria, persiapan dilakukan di Belgia dan dilakukan di Prancis dengan memanfaatkan keragaman warga negara Prancis," ujar Hollande.

Pihak berwajib telah mengidentifikasi lima dari tujuh pelaku terror, empat diantaranya adalah warga negara Prancis dan seorang asing yang sidik jarinya berhasil di data di Yunani bulan lalu. 
Kepolisian Prancis percaya bahwa masih ada satu orang pelaku yang masih melarikan diri.Sebelumnya Senin lalu pihak ISIS telah mengeluarkan ancaman, jika ada negara manapun yang berani menyerang mereka akan bernasib sama seperti Prancis dan target utama mereka adalah Washington, AS. (reuters/and). ${ }^{1}$

\section{Scheme of the News}

a. Analysis of Headline

The headline on the news in this framing analysis study is France Invites the World to Combine ISIS's Combine, This headline consists of nine words. This headline is actually quite long, but it looks short because in the mass media newspapers are permitted and are required to shorten sentences that are widely understood by the reading community. Headline is classified as Headline Teller Headline that seeks to attract the reader's attention by summarizing important news clearly and precisely. The contents of the header teller is usually directly to the target. Headline tellers are often designed using one or two standard fonts. The headline is made in accordance with the facts in the news script. This means the title has described the content of the news. In the title also there is no repeating the same word. The title of news is in the form of opinion news, so the title reflects the opinions of various news person. In the title there is no ambiguity, double meaning, giving various interpretations.

\section{b. Analysis of Lead News}

The first paragraph of the news entitled France Invites the World to Fight ISIS is called news lead in accordance with the news structure which contains elements of $5 \mathrm{~W}$ $+1 \mathrm{H}$. It can be explained that the first $\mathrm{W}$ is Who, is the President of France, the second $\mathrm{W}$ is What, invites the United States and Russia . The third W is Why, to build a global coalition. The fourth $W$ is When (when), is Tuesday (17/11). The fifth is Where (Where) President of France explain or give her press statement. In the tita it has been explained that the delivery of the message took place at a parliamentary joint meeting at the Palace of Versailles, France. This means, news leads according to the news structure that requires good leads contain elements of $5 \mathrm{~W}+1 \mathrm{H}$. While how on the news is on the word to combat ISIS. Nevertheless it is slightly different between news leads with news headlines shown. In the title, France invited the world to coalition against ISIS, while in the news lead the French President invited America and Russia, no word was found on the world.

\footnotetext{
${ }^{1}$ Harian Waspada, 18 November 2015.
} 


\section{c. Background of Information}

In contrast to the above understanding, then the background information in the news entitled France Invite the World berkoalisi Fight ISIS published daily Waspada should be seen what things are the background information formed the news. First, the news came about because of information about the Paris attack. As reported by various international and local mass media as claimed Kompas.com as follows: PARIS, KOMPAS.com - Deadly attacks in Paris that occurred on Friday (13/11/2015) evening local time became the second bloodiest event since the attacks of 11 September 2011 which devastated the World Trade Center building in New York.

\section{d. Analysis of News Source}

On news entitled Framing Analysis French News Invites the World to Combine Corruption ISIS, is the source of news statements from French President Francois Hollande, US President Barack Obama, and French Military Command. This news source is considered credible because they have the highest position in their country. Therefore the news delivered to the public according to the mass media has a value of selling value.

\section{e. Statement}

In the framing analysis on the statements contained in the French news header Invite the World to Combine ISIS is quite important to understand because the statement (statement) which in practice the same as the news sentence. However, the statement has a more specific meaning. A statement is a sentence used to make a claim or convey something that can be true or false.

\section{f. Closing}

An important issue in Pan and Kosicki's framing analysis is the issue of news closing. News with the French title Invites ISIS's Fighting World to be closed with the following news: earlier Monday, then the ISIS had issued a threat, if any country dared to attack they would have the same fate as France and their main target was Washington, USA

\section{Script}

\section{a. $5 \mathrm{~W}+1 \mathrm{H}$}

$5 \mathrm{~W}+1 \mathrm{H}$ contained in the news mentioned above is as follows :

Who : President of Prancis Francois Hollande 
What : France is at war with a threatening jihad terrorist the whole world

Why :Promise to add funds to improve domestic security and strengthen antiterrorism laws

When : Tuesday $(17 / 11)$

Where : Palace of Versailles, Perancis.

How : Invite the world to build a global coalition to fight ISIS.

When observed in terms of the way journalists tell stories (scripts), the completeness of the $5 \mathrm{~W}+1 \mathrm{H}$ element is found as a complete news requirement. From the completeness of the $5 \mathrm{~W}+1 \mathrm{H}$ element, it can be understood that journalists who make news dramatize the French nation's excitement due to the ISIS group's attacks, and at the same time frighten other countries will have the same adverse effects as France itself. It may be that the intention is to seriously finish the ISIS group.

\section{Thematic}

\section{a. Paragraph}

From the news above it can be understood that the statements quoted by reporters that are clearly not opinions, but the facts in the form of information conveyed by French President Francois Hollande invites the United States (US) and Russia, Tuesday (17/11) to build a global coalition to fighting ISIS after a string of attacks in Paris last Friday.

The paragraph in this news includes a good paragraph because it contains the continuity of the sentence in it. The continuity is woven by the similarity of terms between sentences. The fact can be seen in the first paragraph; French President Francois Hollande invited the United States (US) and Russia on Tuesday (17/11) to build a global coalition to fight ISIS after a series of attacks in Paris last Friday.

Nominalitation, on the news mentioned above which is the nomination is the President of France, a spokesman for the French Military Command, and American President Barack Obama.

Coherence on news with the French title Invite the World to Combine Corruption ISIS runs normally on every paragraph, because each sentence 
has a relationship to make a well-understood mindset, but not on coherence between paragraphs.

\section{b. Proportion}

Especially regarding the proportions that can be observed in the analysis of ISIS news framing with the French title Encourage the World to Fight Against ISIS has referred to the inverted pyramid proportions that is by raising the issue more important to the elements of the news starting from the making of the title, news lead, news body, and continues to be increasingly unimportant in closing the news.

\section{Rhetorics}

\section{a. Words}

In the news titled France Encourage a World of Coalition Fighting ISIS there are 252 words in the form of nouns, verbs, adjectives, adverbs, said words, and assignments.

\section{b. Idiom.}

On the news with the French title Invite the World berkoalisi Fight ISIS not found the word idiom is the expression of the language of a combination of words (phrases) whose meaning has been fused and can not be interpreted with the meaning of the elements that form it.

\section{c. Picture/Photo}

Important facts that are not found in news with France Take the ISIS Attack World Coalition to be contained in the Waspada daily are photos of the ISIS region bombarded by 20 bombs by French fighter jets and coalition forces that attack ISIS territory as mentioned on the news content. So with the news published in Mirror Online is also not found a photo of ISIS territory that bombed French troops. 


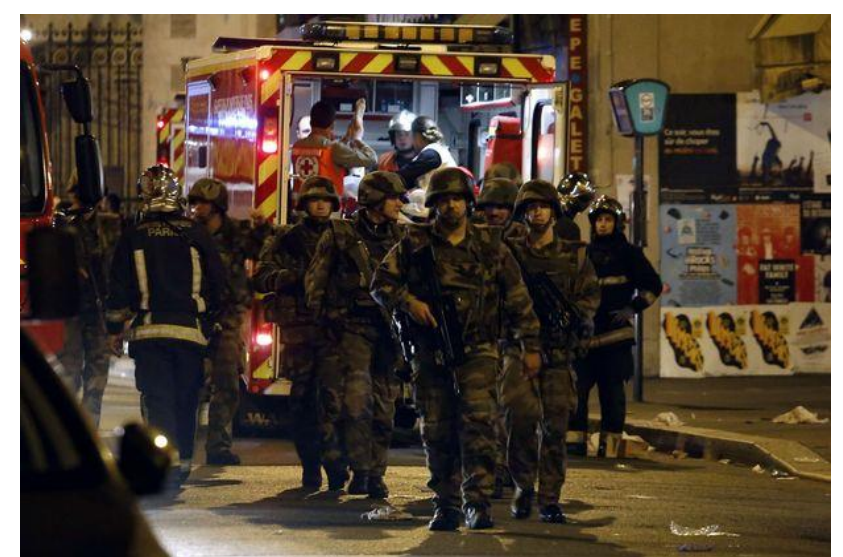

Disaster: At least 129

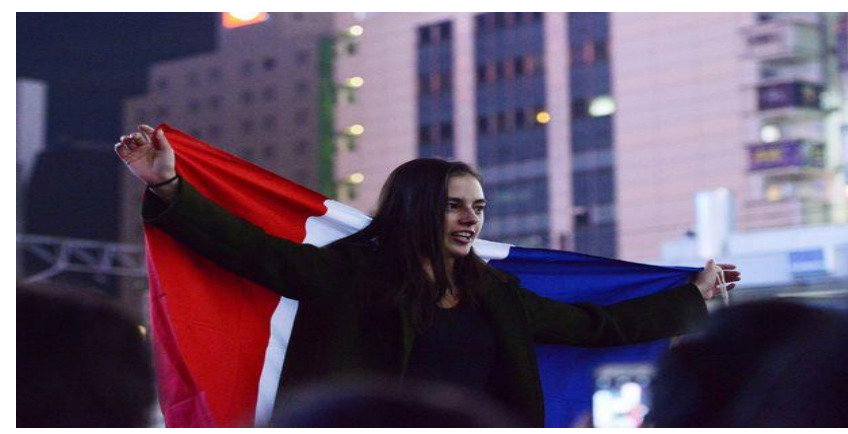

have lost their lives

Solidarity:Support for France has been flooding in from across the globe

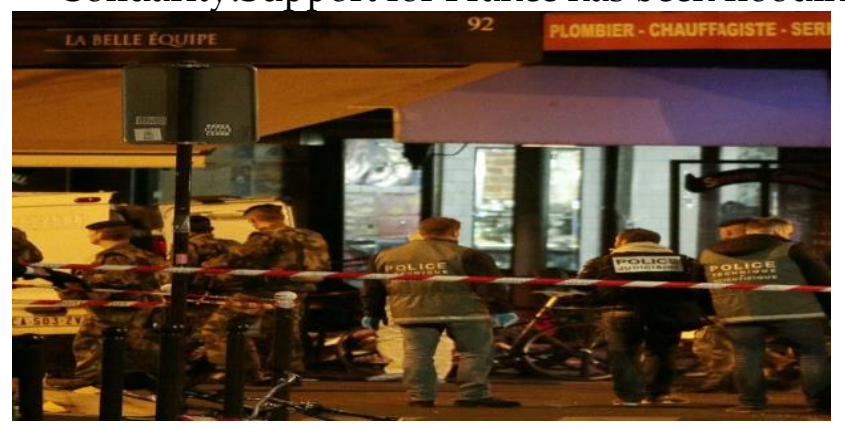

Response: Officers race to central Paris terror attacks

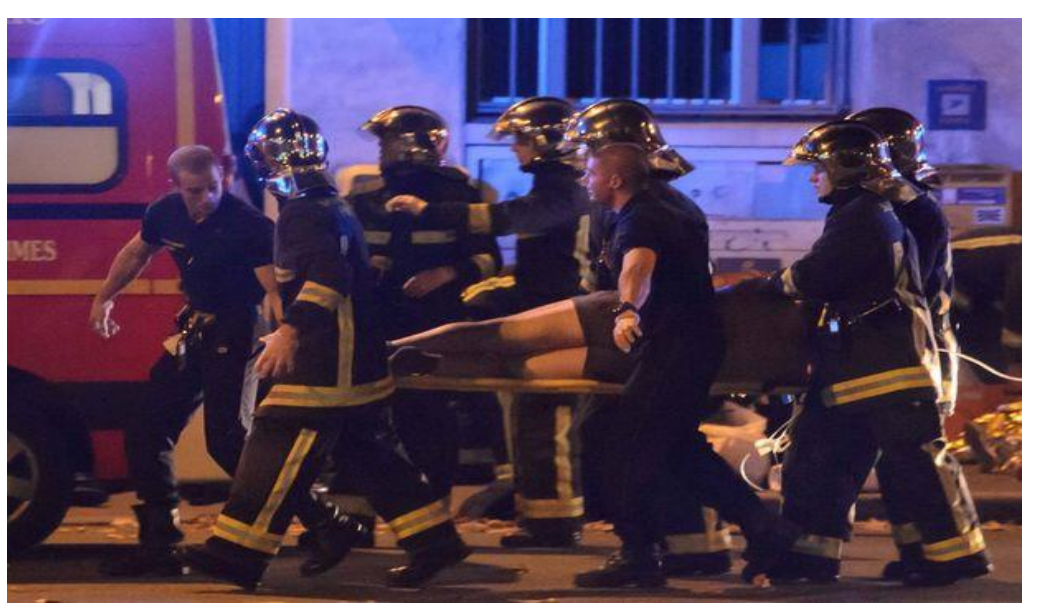


Terror: The attack was the worst on French soil since World War Two

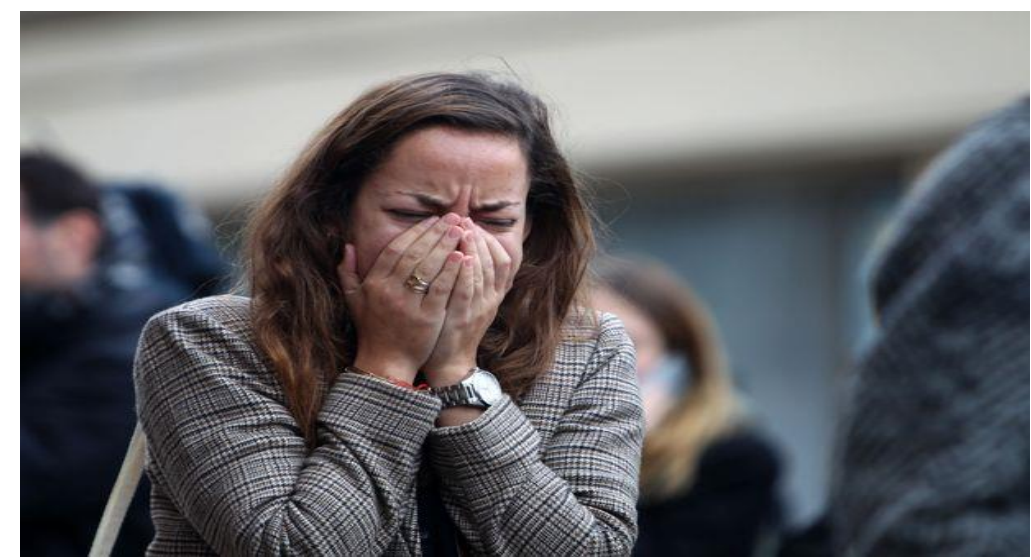

\section{d. Graphics.}

News with the French title Invites ISIS's Fighting World to be published in the Waspada daily found that there were no graphs to support the content of the news, thus making the reader feel unable to understand well the contents of the news, or at least the news did not have a strong appeal for readers. Even so without graphics, of course not to cause suspicion about the authenticity of the content of the news. 


\title{
Framing Analysis on the News of Militant of ISIS Excecuted his Mother
}

\author{
Militan ISIS Eksekusi Ibu Kandungnya
}

RAQQA, Syria (Waspada) : Seorang militan ISIS dikabarkan mengeksekusi mati ibunya sendiri di hadapan ratusan orang di Raqqa, Suriah, daerah yang dianggap sebagai ibu kota de facto dari kekhalifahan kelompok militan tersebut.

Menurut laporan lembaga Syrian Observatory for Human Rights yang dirujuk, ibu tersebut dieksekusi di depan gedung kantor pos di Al-Raqqa, tempat di mana ia bekerja. Semua sumber lembaga tersebut satu suara bahwa ibu itu dieksekusi dengan alasan memaksa putranya untuk meninggalkan ISIS dan kabur bersama ke luar Al-Raqqah dan bahwa koalisi [serangan udara] akan membunuh semua anggota organisasi tersebut.

" Anak berusia 20 tahun tersebut diduga langsung melapor ke ISIS. (Reuters/cnn/and).

1. Scheme of the News

\section{a. Headline}

Based on the analysis that the title has been in accordance with the news scheme as has been revealed above. But it can be understood that the title of the news seeks to attract the attention of readers and simultaneously lead the world's people serious attention to the existence of ISIS. The title requires that the world both hate and fight ISIS, because the existence of ISIS is considered to disturb the peace and security of the world. ISIS is seen as a terrorist who must be fought because it has no moral.

\section{b. Lead of the News}

If we read on the above lead then we will not put forward perfection, because the elements of $5 \mathrm{~W}+1 \mathrm{H}$ are incomplete. Suppose that the Why (why) mother is executed, and when (when) the execution occurs, and how (how) after the execution is done.

\section{c. Source}

Sources of information contained in news titled ISIS Militants The execution of their Mother Mothers was not directly addressed by journalists from the field but the information obtained through the Observatory for Human Rights was an organization formed by pro-opposition opponents of the Bashar al-Assad regime.

\section{d. Stattements}

The statements contained in the contents of the news entitled ISIS Militant Execution of the Birth Mother, only sourced from the information leader of the Observatory for Human Rights, Rami Abdulrahman based on 
reports received from members who are in the field, then Abdulrahman convey this information to western media such as Reuter, CNN, VOA, BBC and others who were later quoted by various other media, including the daily Waspada Medan.

\section{e. Closing}

In the news entitled ISIS Militant The execution of his biological mother published by Waspada daily was closed in the fourth paragraph as follows: The 20-year-old child was allegedly reporting directly to ISIS.

\section{Script}

News with the title ISIS Militant The execution of his biological mother, published by Waspada daily, can be seen in the news elements contained in it which are related to $5 \mathrm{~W}+1 \mathrm{H}$ are as follows :

1. What: Execution of the birth mother

2. Who: an ISIS militant

3. Why: asks to leave ISIS because the coalition will carry out air strikes

4. When: January 2015

5. Where: in front of the post office building in Al-Raqqa

6. How: her mother was killed.

3. Thematic

a. Paragraph.

The above news does not present detailed data, especially concerning the identity of a mother who is the victim of execution and then the name of the child who executes his own biological mother. All identities on this news are obscured by the Waspada Daily. Whereas in other media such as Sindo News.com it was revealed that the name of the mother who was executed was Leena Al-Qasem, 45, and the biological child who executed was Ali Saqr, 20.

b. Proportion

Especially regarding the proportions that can be observed in ISIS news framing analysis with the title ISIS Militant Execution of her biological mother has referred to the inverted pyramid proportions that is by raising the issue more important upwards from the elements of the 
news presented starting from the making of the title, news lead, news body, and continue increasingly unimportant in closing the news.

\section{Rhetoric}

a. Words.

In the news entitled ISIS Militant Execution of the Mother of the Blade there are 95 words either form of nouns, verbs, adjectives, adverbs, said words, or the word task.

a. Idiom.

In the news titled ISIS Militant Execution of the biological mother, the idiom word is not found, namely the language expression in the form of a combination of words (phrases) whose meaning has been fused and cannot be interpreted with the meaning of the elements that compose it

b. Picture/Photo

Important facts that are not found in ISIS Militant news The Execution of His Birth Mothers, published daily Waspada, is a photo of the ongoing execution of a biological child. Though the execution activity was said to take place in front of hundreds of ISIS citizens themselves.

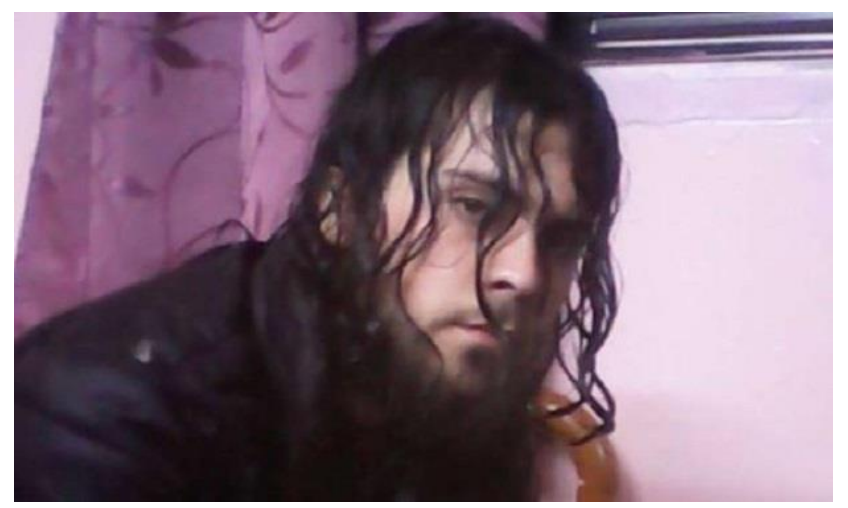



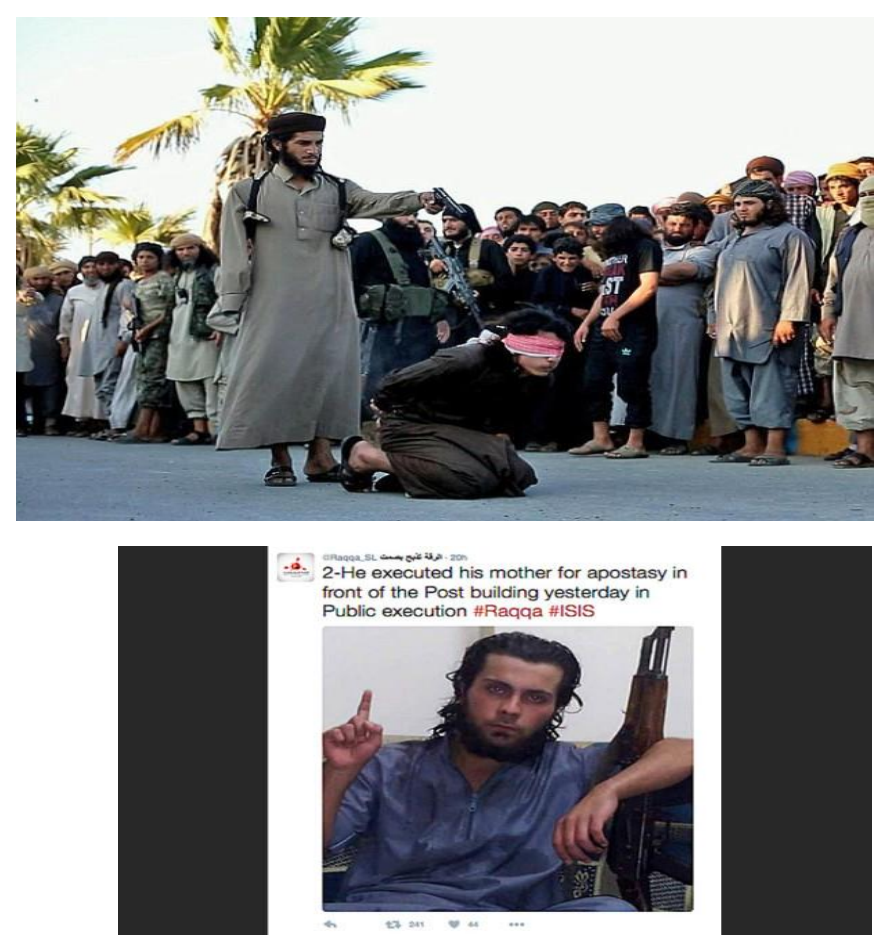

The use of photos in newspapers is important because the photo is the first element that catches the reader's eyes. Then, photos in newspapers can be used to communicate with readers who have diverse backgrounds, because photos are universal.

e. Graphic.

News with the title ISIS Militant Execution The mother of the Blade found no graph to support news content that was able to reveal how many ISIS groups execute biological mother, or biological father, or vice versa. Such graphics are very important as supporting news facts, so the news can be spared from hoax allegations.

\section{CONCLUSION}

After a framing analysis of ISIS news under the title British Women's Testimony About ISIS, France Invites the World to Combat ISIS, and ISIS Militants The execution of their own biological mother who was made and broadcast in print media was included in the Waspada daily quoted by the Reauter news agency. AFP, CNN, and And were not obtained by reporters directly in the field or directly to primary sources, but were obtained through 
secondary sources. Of course the news about ISIS is very doubtful kesahehannya. Because the syntax of the news does not match the news scheme, the news script does not have the completeness of the news, the thematic news is not made in detail, and the structure / rhetoric of the news does not emphasize a particular meaning.

\section{BIBILIOGRAPHY}

Ad Dimasyqi, Al Imam Abul Fida Ismail Ibnu Kasir. Tafsir Ibnu Katsir, Juz 7, Bairut, Libanon : Dar Al-Kutub Al-Ilmiyah.

Ali, Abdullah Yusuf, The Holy Quran,. Wordsworth Editions Ltd; 5th edition, 2001.

Al Jauziyyah, Ibnul Qayyim, Al Fawaa'id. Pustaka Imam Syafii : Jakarta, 2015.

Al-Maraghi, Mushtafa Ahmad, Tafsir Al-Maraghi. Semarang: CV. Toha Putra, 1989.

Al-Qadhi, Imam Muhammad bin 'Ali bin Muhammad bin 'Abdullah asy-Syawkani, ashShan'ani. Fath-hul Qadiir al-Jaami' Bayna Fannay ar-Riwaayah Wa ad-Diraayah Min 'Ilm at-Tafsiir. Dâr al-Fikr: Beirut. juz V.

An Naisaburi, Imam Abu Husain Muslim bin Al Hajjaj. Shahih Muslim. Pustaka As Sunnah.: Jakarta.

Apriadi Tamburaka. Agenda Setting Media Massa. Jakarta : Rajagrafindo Persada. Jakarta. 2012.

Ardianto, Elvinaro. Komunikasi Massa : Suatu Pengantar, edisi revisi.Simbiosa : Bandung. 20005.

Asaad, Muhammad Haidar. ISIS Organisasi Teroris Paling Mengerikan Abad Ini. Jakarta Selatan : PT Zaytuna Ufuk Abadi, 2014.

Badan Pengembangan dan Pembinaan Bahasa. Kamus Besar bahasa Indonesia, Jakarta : Balai Pustaka. 2008.

Chaer, Abdul. Bahasa Jurnalistik. PT Rineka Cipta. 2010.

Cahya, Inung S. Menulis Berita di Media Massa. Yogyakarta: Citra Aji Pratama,2012.

Cohen, Bernard C. The Press and Foreign Policy. Princeton University Press, 1963.

Dan Nimmo. Komunikasi Politik, khalayak dan Efek. Penerjemah Tjun Surjaman. (Remaja Rosdakarya Bandung. 2000.

Edward. Covering Islam : How The Media and The Experd Determine How We See The Rest of The World. New York : Pantheon, 1981.

Effendy , Onong Uchjana. Kamus komunikasi. Jakarta : Mandar Maju, 1989.

Emory A, Griffin. A First Look at Communication Theory, 5th edition. New York: McGrawHill, 2004. 
Eriyanto. Analisis Wacana: Pengantar Teks Media. Yogyakarta: LkiS Goodman. 2012. Hafied Cangara. Pengantar Ilmu Komunikasi. Jakarta : Rajagrafindo Persada. 2001. Imam An-Nawawi, Syarah Shahih Muslim. Darus Sunah : Jakarta.

Indrawan WS. .Kamus Lengkap Bahasa Indonesia. Jombang: Lintas Media, 2000.

Kriyantono, Kriyantono. Teknik Praktis Riset Komunikasi. Kencana Prenada Media Group: Jakarta, 2010.

Lippmann, Walter. Essays in the Public Philosophy. Boston: Little, Brown. 1955.

Lubis, Muchtar. Menuju Jurnalisme Berkualitas. Jakarta : Kepustakaan Populer Gramedia, 2009.

Maxwell McCombs dan Donald Shaw. A Progress Report on Agenda setting Research, dalam E.M. Griffin.

McQuail, Denis, McQuail's Mass Communication Theory, $4^{\text {th }}$ Edition. Sage Publications. 2000.

Moleong, Metode Penelitian Komunikasi Etnografi. Bandung: Remaja Rosdakarya. 2002

Mutawalli, Muhammad al Sya'rawi, Tafsir al-Sya'rawi,Jilid V. ttp: Akhbar al-Yawm, 1991.

Romli, Asep Syamsul M. Jurnalistik Praktis untuk Pemula. Bandung : Penerbit PT Remaja Rosdakarya. 2009.

Rolnicki, Tom E. Dkk. Pengantar Dasar Jurnalisme. Scholastic Journalisme. Jakarta : Kencana Predana Media Group.

Rogers, E.M., Hart, W. B., \& Dearing, J.W, A paradigmatic history of agenda-setting research. In Iyengar, S. \& Reeves, R. (Eds.) Do the media govern Politicians, voters, and reporters in America.Thousand Oak, CA: Sage, 1997.

Said, Prabudi. Sejarah Harian Waspada dan 50 Tahun peristiwa Halaman Satu, 1995.

Shaw, McCombs, M, The Agenda-Setting Function of Mass Media. Public Opinion Quarterly .Harcour : New York. 1972.

Sobur, Alex, Analiss Teks Media: Suatu Pengantar untuk Analisis Wacana, Analisis Semiotik dan Analisis Framing. Bandun r. . nт $\mathbf{D}$ ?maja Rosadakarya, 2006.

Sumadiria, A.S. Haris. Rangkuman Buku 56 tik Indonesia. Jakarta : Kencana Prenada Media Group. 2008. 2014.

Sugiyono, Metode Penelitian Kuantitatif, Kualitatif dan R \& D. Bandung :Alfabeta, 2012.

Stuart Hall. "The Work of Representation". Representation: Cultural Representation and signifying Practices. Ed. Stuart Hall. London : Sage Publication, 2003.

Tahqiq, Imam Abdurrouf Al-Munawi, Faidhul Qodir Syarah Al-Jami' Ash-Shoghir,jilid 4, Darul Ma'rifah: Beirut, 2014.

Taylor dan Bogdan,dalam Suyanto Penghantar Penelitian Ilmiah. Bandung: Tarsito.2006 
Tinarbuko, Sumbo. Semiotika Komunikasi Visual. Yogyakarta: Jalasutra, 2009.

Wijaya, Sri Herwindya Baskara. Masa Depan Media Indonesia. Jakarta : ISKI, 2014.

\section{Internet}

Abuqudairi, Areej (5 July 2014). "Anger boils over in the 'Fallujah of Jordan'". Al Jazeera.

al-Ibrahim, Fouad (22 August 2014). "Why ISIS is a threat to Saudi Arabia: Wahhabism's deferred promise". Al Akhbar.Beirut, Lebanon.

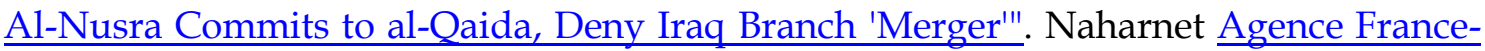
Presse.

Atassi, Basma (9 June 2013). "Qaeda chief annuls Syrian-Iraqi jihad merger". Al Jazeera.

Al Qaeda says it freed 500 inmates in Iraq jail-break". Reuters. 23 July 2013

"Al-Qaeda disavows any ties with radical Islamist ISIS group in Syria, Iraq". The Washington Post. Diakses tanggal 7 February 2014

Al-Qaeda in Iraq confirms Syria's Nusra is part of network". GlobalPost. Agence FrancePresse. 9 April 2013.

Cloud, David S.; Abdulrahim, Raja (21 June 2013). "U.S. training Syrian rebels; White House 'stepped up assistance'". Los Angeles Times.

Crime and punishment in Saudi Arabia: The other beheaders". The Economist. 20 September 2014. Diakses tanggal 7 November 2014.

Fahny, Omar; Bayoumy, Yara (16 February 2015). "Egypt bombs Islamic State targets in Libya after 21 Egyptians beheaded".

Gaouette, Nicole; Ajrash, Kadhim; Sabah, Zaid (23 June 2014). "Militants Seize IraqJordan Border as Kerry Visits Baghdad". Bloomberg News.

https://id-mg61,mail.yahoo.com//neo//launch?.rand=121d6goh7ctze

https://www.islampos.com/penelitian-pusat-kajian-timur-tengah-ui-mengenai-isis220609.

Hussain, Ghaffar (30 June 2014). "Iraq crisis: What does the Isis caliphate mean for global jihadism?". The Independent (London).

International.sindonews.com/read/1047569/41/putin-ideologi-isis-didasarikebohongan-dan-membelokan-ajaran-islam-1443009473.

ISI Confirms That Jabhat Al-Nusra Is Its Extension in Syria, Declares 'Islamic State of Iraq And Al-Sham' As New Name of Merged Group". MEMRI. Middle East Media Research Institute. 8 April 2013.

Irke, Sarah (27 December 2013). "How al-Qaeda Changed the Syrian War". New York Review of Books. 
Framing Analysis bn News of Islamic State of Iraq and Syiria In Waspada Daily News DOI: 10.30575/2017/IJLRES-2018050812

Lucas, Mary Grace (13 October 2014). "ISIS nearly made it to Baghdad airport, top U.S. military leader says". CNN.

Platov, Vladimir (18 January 2014). "Growth of International Terrorist Threat from Syria". New Eastern Outlook. Diakses tanggal 11 June 2014.

Joscelyn, Thomas (27 November 2013). "Chechen-led group swears allegiance to head of Islamic State of Iraq and Sham". Long War Journa.

Saad, Hwaida; Gladstone, Rick "Qaeda-Linked Insurgents Clash With Other Rebels in Syria, as Schism Grows". The New York Times, 4 January 2014.

Shihab, M. Quraish. Tafsir Al Misbah. jilid 13.Jakarta : Lentera Hati, 2012.

Solomon, Erika; Kerr, Simeon (3 July 2014). "Saudi Arabia sends 30,000 troops to Iraq border". Financial Times.

Speckhard, Anne (29 August 2014). "Endtimes Brewing". Huffington Post (UK) Syrian branch of al Qaeda vows loyalty to Iraq's ISIS"

Solomon, Erika; Kerr, Simeon (3 July 2014). "Saudi Arabia sends 30,000 troops to Iraq border". Financial Times.

What does ISIS' declaration of a caliphate mean?". Al Akhbar English 